\title{
Some Reproductive Characteristics of the Beysehir Dace (Squalius anatolicus Bogutskaya, 1997) in Oymapınar Dam Lake Antalya, Turkey ${ }^{[*]}$
}

\author{
Elif SARI Zehra Arzu BECER* \\ Department of Basic Fisheries Sciences, Faculty of Fisheries, Akdeniz University, Konyaalt, Antalya, Turkey
}

How to cite: Becer, Z.A., \& Sarı, E. (2021). Some Reproductive Characteristics of the Beysehir Dace (Squalius anatolicus Bogutskaya, 1997) in Oymapınar Dam Lake Antalya, Turkey. J. Anatolian Env. and Anim. Sciences, 6(4), 560-566.

Atıf yapmak için: Becer, Z.A., \& Sarı, E. (2021). Oymapınar Baraj Gölü’ndeki (Antalya, Türkiye) Beyşehir Tatlısu Kefalinin (Squalius anatolicus Bogutskaya, 1997) Bazı Üreme Özellikleri. Anadolu Çev. ve Hay. Dergisi, 6(4), 560-566.

D: https://orcid.org/0000-0002-7277-0210

iD : https://orcid.org/0000-0002-2793-4503

\begin{abstract}
This study was conducted in Oymapınar Dam Lake from March 2016 to February 2017. The study investigated the age composition, spawning season, sex ratio, age and length at first sexual maturity, and fecundity of Beysehir dace (S. anatolicus). The ages of the 422 Beysehir daces sampled from Oymapınar Dam Lake ranged from II to VIII of which $200(47.39 \%)$ were females and $222(52.61 \%)$ were males. The fork lengths and weights of female Beysehir daces varied between $20.0 \mathrm{~cm}$ and $55.1 \mathrm{~cm}$ and $93.37 \mathrm{~g}$ and $2307.88 \mathrm{~g}$ respectively. The oldest age group was VIII for females and VII for males. The length at first sexual maturity for females and males were $26.0 \mathrm{~cm}$ and $23.0 \mathrm{~cm}$, respectively and the age at first sexual maturity for females and males were III and II, respectively. This shows that males mature earlier than females. Monthly gonadosomatic index values showed that the peak spawning period for Beysehir daces was between April and June. The fecundity (F) - length relationship of $S$. anatolicus was $\operatorname{LogF}=-$ $0.44697+3.33868 * \operatorname{LogL}\left(\mathrm{R}^{2}=0.7168\right)$. The mean egg diameter of $S$. anatolicus was $0.93 \mathrm{~mm}$ and the average fecundity was 78408 .
\end{abstract}

\section{Keywords: Beysehir freshwater mullet, oymapınar dam lake, reproduction, sexual maturity, Squalius anatolicus. \\ Corresponding author's: \\ Department of Basic Fisheries Sciences, \\ Konyaalt, Antalya, Turkey \\ $凶: \underline{\text { abecer@akdeniz.edu.tr }}$ \\ Oymapınar Baraj Gölü'ndeki (Antalya, Türkiye) Beyşehir Tatlısu Kefalinin (Squalius anatolicus Bogutskaya, 1997) Bazı Üreme Özellikleri}

*Sorumlu yazar:

Zehra Arzu BECER

Akdeniz Üniversitesi, Su Ürünleri Fakültesi,

Su Ürünleri Temel Bilimler Bölümü,

Konyaaltı, Antalya, Türkiye

凶: abecer@akdeniz.edu.tr
Öz: Bu çalışmada; Oymapınar Baraj Gölü’nden Mart 2016 - Şubat 2017 tarihleri arasında örneklenen Beyşehir tatlısu kefalinin (S. anatolicus)'nin yaş kompozisyonu, yumurtlama zamanı, eşey oranları, ilk eşeysel olgunluğa erişme boyu ve yaşı, fekonditesi araştırılmıştır. Oymapınar Baraj Gölü'nden örneklenen 422 Beyşehir tatlısu kefalinin yaşları II-VIII arasında dağılım göstermiş, Örneklerin \% 47,39'nu dişiler, \% 52,61'ini erkekler oluşturmuştur. Dişilerin çatal boylarının 20,0 cm ile 55,1 cm arasında, ağırlıklarının ise 93,37 $\mathrm{g}$ ile 2307,88 $\mathrm{g}$ arasında değiştiğ saptanmıştır. En büyük yaş dişiler için VIII, erkekler için VII olarak belirlenmiştir. İlk eşeysel olgunluk boyu dişi ve erkek Beyşehir tatlısu kefali bireylerinde sırasıyla $26,0 \mathrm{~cm}$ ve $23,0 \mathrm{~cm}$ olarak hesaplanmıştır. İlk eşeysel olgunluk yaşı dişi bireyler için III, erkek bireyler için ise II olarak bulunmuştur. Bu, erkeklerin dişilerinden daha erken olgunlaştı̆̆ını göstermektedir. Aylık gonadosomatik indeks değerleri, yumurtlama zamanın yoğun olarak Nisan-Haziran ayları arasında olduğunu göstermiştir. Fekondite $(\mathrm{F})$ - boy ilişkisi, $\operatorname{LogF}=-0,44697+3,33868 * \operatorname{LogL}\left(\mathrm{R}^{2}\right.$ $=0,7168$ ) olarak saptanmıştır. Ortalama yumurta çapının $0,93 \mathrm{~mm}$ ve ortalama yumurta veriminin 78408 adet/birey olduğu belirlenmiştir.

Anahtar kelimeler: Beyșehir tatlısu kefali, eșeysel olgunluk, oymapınar baraj gölü, Squalius anatolicus, üreme. 


\section{INTRODUCTION}

Dam lakes, which have been constructed for irrigation, hydroelectric energy, flood protection, fishing, drinking and irrigation water purposes in many regions of Turkey play an important role in aquaculture production. In addition, the reservoirs formed behind the dams possess important potential in terms of sport and commercial fishing. Closing the river with a set causes extremely important changes to occur in terms of living creatures in the environment (Kırankaya \& Ekmekçi, 2007). Oymapınar Dam Lake, which constitutes the research area of this study is one of the dam lakes established to provide hydroelectric power generation, drinking and irrigation water in Turkey.

The fact that the dams and ponds in Turkey have a great potential in terms of aquaculture has revealed the need to evaluate the areas from this perspective, and biological studies on fish species in many dams and natural lakes have increased. There are very few biological studies on the Beysehir dace population in the different dam lakes of Turkey. The few studies from the lakes and dam lakes of Turkey on the growth, reproduction age and condition factors of chubs are reviewed in this study. However, in Oymapınar dam lake, there has not been any work related to fisheries. There is no information on the reproductive biology of Beysehir dace in Oymapınar dam lake. Due to this, there is no information on the changes in the reproductive characteristics, reasons for the increase or decrease in the population of Beysehir daces in Oymapınar dam lake.

Therefore, the purpose of this study was to determine some reproductive characteristics of $S$. anatolicus in the Oymapınar dam lake monthly for one year, and establish baseline data on the sex ratio, fecundity, age, and length at first sexual maturity, and spawning seasons of Beysehir dace population in Oymapınar Dam Lake. The knowledge of fish reproductive biology is very important for the rational utilization of fish stocks and their sustainable production (Cochrane, 2002; Temesgen, 2017). Understanding the reproductive aspects of fish is also very important for providing sound scientific advice in fishery management (Hossain et al., 2017; Khatun et al., 2019; Tessema et al., 2020). The findings of this study will contribute to future studies and measures to be implemented in fisheries management studies in terms of determining and evaluating the status and design management strategy for the population of Beysehir daces in the Oymapinar dam lake.

\section{MATERIALS AND METHODS}

Study Area and Fish Sampling: The study was conducted in Oymapınar dam lake. Oymapınar dam lake is in the district of Manavgat, Antalya Province, in southern Turkey. Oymapınar dam lake, which is $76 \mathrm{~km}$ away from Antalya province, is a dam lake built on the Manavgat river between 1977-1984 to generate electrical energy. The dam, which is a concrete arch type, has a body volume of $575,000 \mathrm{~m}^{3}$, a height of $185 \mathrm{~m}$ from the stream bed, a lake volume of $300.00 \mathrm{hm}^{3}$ at normal water elevation, and a lake area of $4.70 \mathrm{~km}^{2}$ at normal water elevation Aykurt \& Altınok, (2009). Oymapınar dam lake produces $1620 \mathrm{GWh}$ of electrical energy per year with a hydroelectric power plant with a power capacity of $540 \mathrm{MW}$ (Anonymous, 2021). The lake lies between latitude $36.908628^{\circ} \mathrm{N}$ and longitude $31.531694^{\circ} \mathrm{E}$ in the Antalya province of Turkey.

Fish samples were collected from March 2016 to February 2017. A total of 422 Beysehir daces were sampled using $100 \mathrm{~m}$ long and $2.5 \mathrm{~m}$ depth monofilament gillnets $(20,30,40,50 \mathrm{~mm}$ mesh size) from seven stations across different parts of the Oymapınar dam lake. The random sampling method was applied in this study. The nets were thrown and collected the next day.

\section{Determination of some Reproduction Characteristics of Beysehir Daces \\ Sex Ratio: The sexes of the sampled fish were} determined by opening the abdominal regions with the help of a dissecting scissors and macroscopic and microscopic examination of the gonads. The ovaries and testes maturities were evaluated based on milky white, smooth surface gonads testis, granular surface, yellowish colours (Karataş et al., 2005).

Maturity Estimation: The age and length at first sexual maturity, according to the maturity ratio of the fish in the spawning period was evaluated using the logistic regression model:

$$
\mathrm{P}=1 /\left[1+\exp ^{(-\mathrm{r}(\mathrm{L}-\mathrm{Lm})}\right] \text { and } \mathrm{P}=1 /\left[1+\exp ^{(-\mathrm{r}(\mathrm{t}-\mathrm{tm})}\right] .
$$

"P" in the equation shows the sexual maturity rates $(\%)$ of each length and age group, "L" is the average length of each age group $(\mathrm{cm})$, "Lm" is the first sexual maturity length, " $t$ " is the age group, "tm" refers to the age at first sexual maturity, " $r$ " refers to the curve of the logistic function (Ricker, 1973).

Spawning Season: The spawning seasons of Beysehir daces were determined based on monthly variations of the gonadosomatic index (GSI). The GSI value was calculated using Ricker's (1975) equation: GSI= $(\mathrm{GW} / \mathrm{W}) * 100$ 
In the equation, "GW" indicates gonad weight, "W" indicates body weight. The spawning season was determined from the monthly GSI values.

Egg Diameter: Eggs taken from the gonads of mature fish that did not shed their eggs during the breeding period were used to measure the egg diameter. The gonads of the dissected individuals were removed, weighed, and stored in $4 \%$ formaldehyde solution. Ten eggs were taken from mature ovaries from the anterior, middle, and posterior parts of the gonads, and their diameters were measured by taking photographs with the SOIF MD30 branded imaging microscope with the help of the M-shot v1.0 computer software.

Fecundity: Egg yield (Fecundity) was determined gravimetrically (Bagenal \& Tesch, 1978), by counting the number of eggs in the ovaries of mature fish that did not shed their eggs during the spawning period. The exponential relationship between fecundity and length $(\mathrm{F}=$ a. $\mathrm{L}^{\mathrm{b}}$ ) was converted into a linear equation by taking the $\mathrm{Ln}$ of both sides of the equation, and the fecundity (F)-length relation $(\mathrm{L})$ was determined using the equation:

$\log F L=\log a+b * \log L$.

The linear relationship between fecundity $(\mathrm{F})$ and weight (W), and fecundity (F) and age (A) was determined using the formulas: $\mathrm{FW}=\mathrm{a}+\mathrm{b} * \mathrm{~W}$ and $\mathrm{FA}=\mathrm{a}+\mathrm{b} * \mathrm{~A}$, respectively (Avşar, 2005).

Data Analysis: Descriptive statistics (frequency, percentages, graphs, and tables) and chi-square $\left(\chi^{2}\right)$ test were used to compare the number of males and females in age groups (Düzgüneş et al., 1987; Kaptan, 1995).

IBM SPSS Statistics 21 for Windows" package program and (FISAT II) (Gayanilo et al., 1996) were used to summarize the collected data. $\mathrm{P}=0.05$ confidence limit was used for statistical significance control. All means are given with \pm standard errors (SE).

In groups with two or more independent groups, the homogeneity of the variances of the data before the ttest was performed with the Levene's test, and before the $\mathrm{t}$ test, to see whether the data showed normal distribution, the data were tested with the Kolmogorov-Smirnov (K-S) test. In cases where the t-test could not be performed, the Mann-Whitney U Test, an alternative nonparametric test, was used.

\section{RESULTS}

\section{Population Structure}

Age and Sex Distribution: The age of the 422 Beysehir daces sampled from Oymapınar Dam Lake ranged from age group II to VIII, of which 200 (46.39\%) were females and $222(52.61 \%)$ were males. The ratio of females to males was $0.90: 1.00$. The most dominant age group in the population, in both sexes, was age group II.
Sex distributions according to age groups are given in Figure 1. The Chi-square $\left(\chi^{2}\right)$ test analysis showed that the differences between all age groups and the sex ratio of Beysehir daces were not statistically significant $(P \geq 0.05)$.

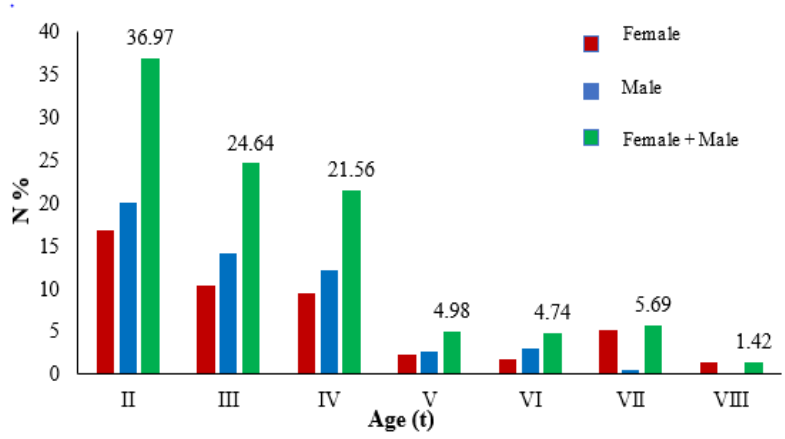

Figure 1. Sex distribution of Beysehir dace by age group (N \%).

Length Distribution: The fork lengths of the 422 Beysehir daces sampled from Oymapınar Dam Lake, ranged between $20 \mathrm{~cm}$ and $55.1 \mathrm{~cm}$, and individuals in the $26 \mathrm{~cm}$ and $30 \mathrm{~cm}$ length groups were found to predominate in the population with a total rate of $47.16 \%$ (Figure 2). The fork lengths of the female fish varied between $20 \mathrm{~cm}$ and $55.1 \mathrm{~cm}$, and the fork lengths of the male fish ranged from $20 \mathrm{~cm}$ to $51 \mathrm{~cm}$.

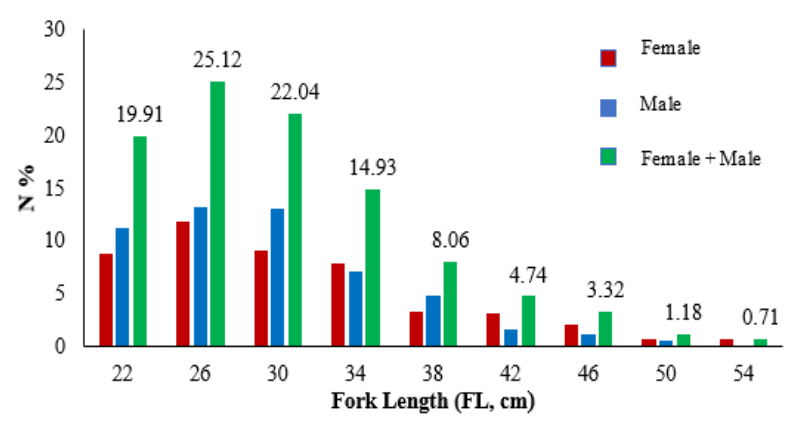

Figure 2. Length distribution of Beysehir dace by sex group (N $\%)$.

\section{Reproduction in the Population}

Age and length at First Sexual Maturity: For the age and length of Beysehir dace at first sexual maturity, 184 individuals sampled between March and June 2016 were taken into consideration. The maturation rates by age groups and the length range of the Beysehir dace sampled from Oymapınar Dam Lake are given in Table 1 and Table 2 , respectively. The age distribution in the examined female Beysehir dace samples showed that $19 \%$ of age group II were sexually matured, $80 \%$ of age group III were sexually matured, $79 \%$ of age group IV were sexually matured while all individuals belonging to higher age groups were sexually matured. While for the examined male Beysehir dace samples, $66 \%$ of the age group II were sexually matured, $94 \%$ of age group III were sexually 
matured and all individuals belonging to higher age groups were sexually matured.

When the maturation rates of Beysehir dace samples were examined according to length groups, it was observed that female individuals reached sexual maturity from $26 \mathrm{~cm}$ length and male individuals from $23 \mathrm{~cm}$ length (Table 1). The application of the sigmoid logistic curve model to the rate at which male and female individuals reach sexual maturity, the length $\left(\mathrm{Lm}_{50}\right)$ at which $50 \%$ of the females got to maturity was $25.51 \mathrm{~cm}$. Sigmoid curves created using the formula:

$$
\mathrm{P}(\mathrm{L})=100 /[1+\exp (-0,417 *(\mathrm{~L}-25,51)]
$$

The length at which $50 \%$ of the male individuals reach maturity $\left(\mathrm{Lm}_{50}\right)$ was $23.35 \mathrm{~cm}$ and the sigmoid curve formula is given as:

$$
\mathrm{P}(\mathrm{L})=100 /[1+\exp (-0.154 *(\mathrm{~L}-23.35))] \text { as }
$$
given in Figure 3.

Table 1. Maturation rates of Beysehir dace samples by age

\begin{tabular}{|c|c|c|c|c|c|c|c|c|}
\hline \multicolumn{9}{|c|}{ Age } \\
\hline & & II & III & IV & V & VI & VII & VIII \\
\hline \multirow[t]{2}{*}{ Female } & & 16 & 30 & 14 & 6 & 6 & 11 & 2 \\
\hline & $\mathbf{N} \%$ & 19 & 80 & 79 & 100 & 100 & 100 & 100 \\
\hline \multirow[t]{2}{*}{ Male } & $\mathbf{N}$ & 38 & 32 & 23 & 1 & 4 & 1 & - \\
\hline & $\mathbf{N} \%$ & 66 & 94 & 100 & 100 & 100 & 100 & - \\
\hline
\end{tabular}
groups.

Table 2. Maturation rates of Beysehir dace samples by length ranges

\begin{tabular}{llllllllllllll}
\multicolumn{11}{c|}{ Length $(\mathrm{cm})$} \\
\hline 21 & 22 & 23 & 24 & 25 & 26 & 27 & 28 & 29 & 30 & 31 & 32 & 33 & $34 \geq$
\end{tabular}

\begin{tabular}{llllllllllllllll}
\hline Female & $\mathbf{N}$ & - & 4 & 1 & 3 & 7 & 4 & 7 & 6 & 4 & 7 & 4 & 2 & 6 & 30 \\
& $\mathbf{N}$ & - & 0 & 0 & 33 & 29 & 50 & 71 & 83 & 50 & 100 & 100 & 100 & 83 & 100 \\
& & & & & & & & & & & & & & & \\
Male & $\mathbf{N}$ & 3 & 4 & 7 & 9 & 11 & 8 & 5 & 9 & 5 & 6 & 6 & 5 & 4 & 17 \\
& $\mathbf{N}$ & 0 & 0 & 57 & 55 & 100 & 100 & 100 & 78 & 100 & 100 & 100 & 100 & 100 & 100
\end{tabular}

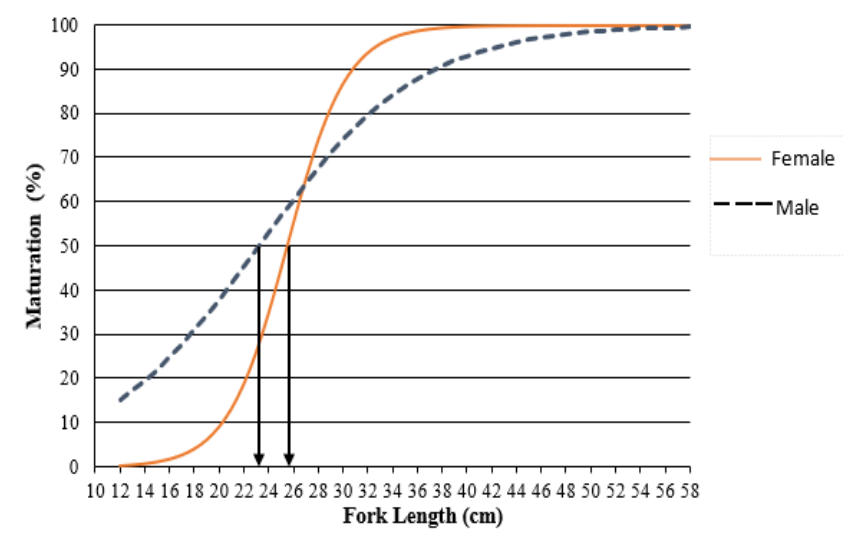

Figure 3. The logistic curve showing the maturity of $50 \%$ of female and male Beysehir dace.

Spawning Season: The spawning season was determined by monitoring the average gonadosomatic index values (GSI) of mature fish monthly. Gonad's development was determined by microscopic examination of the ovary and testicles (Figure $4 a, b)$. The monthly average gonadosomatic index values of female and male Beysehir daces are given in Table 3. Table 3 shows that the female Beysehir daces reached the highest GSI value (3.32) in April. The values started decreasing from May and the lowest recorded GSI value of 1.20 was in June (Table 3). In male Beysehir dace, the GSI values was highest in March (4.02) and started decreasing from April till the lowest recorded GSI value of 0.78 in June Table 3.

Table 3. Monthly average GSI values of Beysehir dace.

\begin{tabular}{lrrrrrrrr}
\hline \multirow{2}{*}{ Months } & \multicolumn{4}{c}{ Female } & \multicolumn{6}{c}{ Male } \\
\cline { 2 - 9 } & $\mathrm{N}$ & GSI \pm SE & $\min$ & \multicolumn{1}{c}{ Max } & N & GSI \pm SE & Min & $\max$ \\
\hline March 2016 & 13 & $3.14 \pm 0.72$ & 0.41 & 7.98 & 16 & $4.02 \pm 0.54$ & 0.77 & 7.65 \\
April 2016 & 42 & $3.32 \pm 0.59$ & 0.33 & 15.84 & 36 & $3.13 \pm 0.41$ & 0.31 & 8.81 \\
May 2016 & 18 & $2.26 \pm 0.42$ & 0.54 & 6.84 & 25 & $1.74 \pm 0.31$ & 0.24 & 5.03 \\
June 2016 & 11 & $1.20 \pm 0.40$ & 0.44 & 5.17 & 22 & $1.05 \pm 0.12$ & 0.31 & 2.27 \\
July 2016 & 8 & $0.73 \pm 0.10$ & 0.49 & 1.35 & 15 & $0.72 \pm 0.05$ & 0.21 & 1.20 \\
August 2016 & 12 & $0.96 \pm 0.12$ & 0.57 & 2.16 & 16 & $0.78 \pm 0.05$ & 0.38 & 1.09 \\
September 2016 & 17 & $1.12 \pm 0.17$ & 0.18 & 3.42 & 20 & $1.09 \pm 0.13$ & 0.42 & 3.05 \\
October 2016 & 17 & $1.06 \pm 0.17$ & 0.17 & 2.74 & 21 & $0.94 \pm 0.10$ & 0.19 & 2.39 \\
November 2016 & 26 & $1.79 \pm 0.31$ & 0.19 & 5.46 & 24 & $1.16 \pm 0.16$ & 0.18 & 2.92 \\
December 2016 & 15 & $2.00 \pm 0.49$ & 0.54 & 6.36 & 12 & $2.14 \pm 0.26$ & 0.19 & 3.72 \\
January 2017 & 12 & $1.39 \pm 0.57$ & 0.19 & 7.06 & 3 & $2.69 \pm 0.11$ & 2.51 & 2.90 \\
February 2017 & 8 & $2.30 \pm 0.54$ & 0.56 & 4.46 & 12 & $2.50 \pm 0.36$ & 0.42 & 4.86 \\
\hline
\end{tabular}

Egg Diameter: The monthly egg diameter ( $\mathrm{mm})$ of 42 female Beysehir daces in the breeding period are given in Table 4. The largest mature egg diameter measured was in April (1.39) while the smallest mature egg diameter measured was in February (0.66).

Table 4. Monthly measured mean, minimum and maximum egg diameter values $(\mathrm{mm})$ of Beysehir daces during the spawning season.

\begin{tabular}{lllll}
\hline Months & N & Egg diameter \pm SE & Min & Max \\
\hline March, 2016 & 8 & $0.93 \pm 0,08$ & 0.70 & 1.38 \\
April, 2016 & 13 & $1.09 \pm 0,06$ & 0.84 & 1.39 \\
May, 2016 & 6 & $0.96 \pm 0,05$ & 0.78 & 1.08 \\
June, 2016 & 1 & 1.22 & 1.22 & 1.22 \\
November, 2016 & 6 & $0.71 \pm 0,05$ & 0.54 & 0.87 \\
December, 2016 & 3 & $0.75 \pm 0,06$ & 0.68 & 0.87 \\
January, 2017 & 1 & 0.87 & 0.87 & 0.87 \\
February, 2017 & 4 & $0.78 \pm 0,05$ & 0.66 & 0.92 \\
Total & 42 & $0.93 \pm 0,03$ & 0.54 & 1.38 \\
\hline
\end{tabular}

Egg yield (Fecundity): The fecundity (F) was determined by counting the eggs in the ovaries of 42 mature Beysehir daces. The total number of eggs in individual Beysehir dace varied between 16116 and 208134. The relative egg yields of female Beysehir daces, whose eggs were counted varied according to age, fork length and body weight as shown in Table 5. It was observed that the egg yields and the number of eggs per unit length $(\mathrm{F} / \mathrm{FL})$ increased with age except for age group VI. The relationships between total egg number and fork length, body weight and age and the regression curves of these relationships are presented in Figure 4, Figure 5, and Figure 6. 


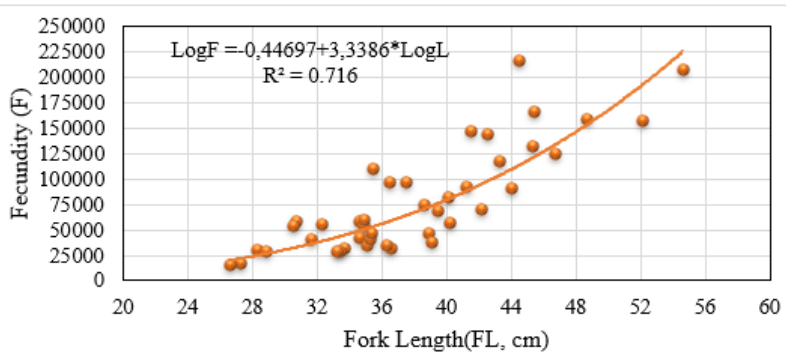

Figure 4. Fecundity-fork length relationship of Beysehir dace.

Table 5. Relative egg yields of Beysehir dace determined by age, fork length and body weight.

\begin{tabular}{ccccccc}
\hline Age & $\mathbf{N}$ & $\begin{array}{c}\mathbf{F L} \pm \mathbf{S E} \\
(\mathbf{m i n}-\mathbf{m a x})\end{array}$ & $\begin{array}{c}\mathbf{W} \pm \mathbf{S E} \\
(\mathbf{m i n}-\mathbf{m a x})\end{array}$ & $\begin{array}{c}\mathbf{F} \pm \mathbf{S E} \\
(\mathbf{m i n}-\mathbf{m a x})\end{array}$ & $\begin{array}{c}\mathbf{F} / \mathbf{F L} \pm \mathbf{S E} \\
(\mathbf{m i n}-\mathbf{m a x})\end{array}$ & $\begin{array}{c}\mathbf{F} / \mathbf{W} \pm \mathbf{S E} \\
(\mathbf{m i n}-\mathbf{m a x})\end{array}$ \\
\hline III & 5 & $28.30 \pm 0.93$ & $307.79 \pm 25.74$ & $29306 \pm 6750$ & $1016 \pm 208$ & $92 \pm 93$ \\
& & $(26.60-30.50)$ & $(255.59-380.00)$ & $(16116-53776)$ & $(606-1763)$ & $(60-142)$ \\
\hline IV & 12 & $33.70 \pm 1.03$ & $489.39 \pm 66.77$ & $50349 \pm 6496$ & $1489 \pm 182$ & $102 \pm 11$ \\
& & $(30.70-35.50)$ & $(387.57-597.02)$ & $(28458-115139)$ & $(853-3114)$ & $(57-185)$ \\
\hline V & 6 & $36.26 \pm 1.78$ & $671.76 \pm 67.05$ & $58084 \pm 12415$ & $1593 \pm 329$ & $86 \pm 15$ \\
& & $(35.30-37.30)$ & $(546.67-776.31)$ & $(31675-96875)$ & $(865-2469)$ & $(41-136)$ \\
\hline VI & 4 & $39.02 \pm 2.40$ & $824.42 \pm 117.26$ & $57191 \pm 8824$ & $1466 \pm 227$ & $70 \pm 11$ \\
& & $(38.60-39.50)$ & $(773.46-880.75)$ & $(38184-74760)$ & $(977-1937)$ & $(97-279)$ \\
\hline VII & 12 & $43.70 \pm 2.00$ & $1128.98 \pm 97.27$ & $120086 \pm 13021$ & $2767 \pm 282$ & $105 \pm 9$ \\
& & $(40.10-46.70)$ & $(921.55-1450.98)$ & $(57221-216801)$ & $(1423-4872)$ & $(62-165)$ \\
\hline VIII 3 & $51.80 \pm 6.06$ & $1927.44 \pm 406.68$ & $174710 \pm 16730$ & $3364 \pm 236$ & $92 \pm 8$ \\
& & $(48.70-54.60)$ & $(1535.22-$ & $(156643-$ & $(3007-3812)$ & $(75-104)$ \\
& & $2158.34)$ & $208134)$ & & \\
\hline
\end{tabular}

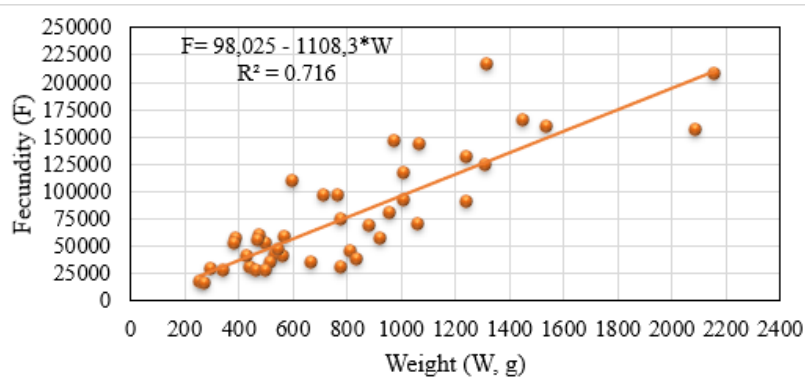

Figure 5. Fecundity-weight relationship of Beysehir dace.

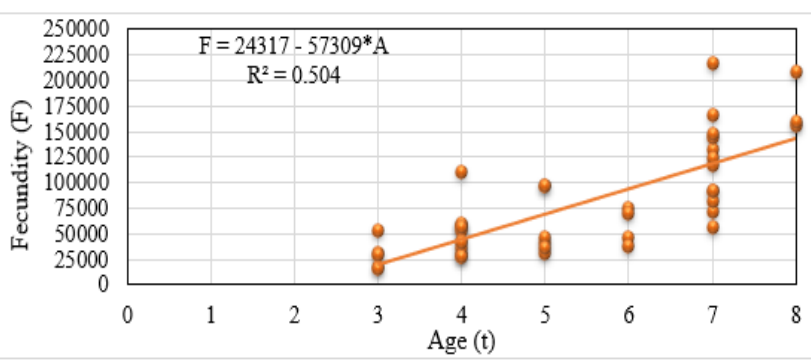

Figure 6. Age-fecundity relationship of Beysehir dace.

\section{DISCUSSION}

The study was conducted to determine some reproductive characteristics of 422 Beysehir daces (Squalius anatolicus Bogutskaya, 1997) in Oymapınar Dam Lake. This is the first report on the reproduction of $S$. anatolicus in Oymapınar Dam Lake and will be used as basic and baseline information. The age groups of the sampled individuals varied from II-VIII. Due to the mesh opening of the fishing gear used, 0 and I age groups of fish were not caught. The result of this study showed that the predominant age group in the population of Beysehir daces in Oymapınar Dam Lake was age group II (36.97\%), this was followed by age group III and IV with $24.64 \%$ and $21.56 \%$, respectively. In both female and male Beysehir daces, age group II predominated the population (Female $16.82 \%$, Male $20.14 \%$ ).

However, the oldest recorded age group in this study for females was VIII and VII for males. Kara and Solak reported an age range of I-VI for the chub population in Keban Dam Lake Turkey while Demirol et al., (2016) reported an age range of $0-\mathrm{XI}$ for the chub population in Uzunçayır Dam Lake Turkey. In the present study, 47.39\% of the Beysehir dace in Oymapınar Dam Lake are females and $52.61 \%$ are males. The sex ratio (F: $\mathrm{M}$ ) in this study was $0.90: 1.10$. The chi-square $\left(\chi^{2}\right)$ test analysis did not show any significant differences between all age groups and the sex ratio of Beysehir dace $(\mathrm{P} \geq 0.05)$. This result agrees with the report of Tümgelir et al., (2007) which recorded a higher male to female ratio (1:1.31) for the population of chubs in Lake Beyşehir, Turkey. The higher male ratio reported in this study is also in agreement with the findings of Demirol et al., (2016) for the chub population in Uzunçayır Dam Lake with a male/female ratio of 1:0.95. Balık et al., (2004) also reported a lower female to male ratio $40.72 \%$ for females and $59.28 \%$ for males in Işıklı Lake, Turkey. But the findings of this study disagree with the report of $72.89 \%$ for females and $27.11 \%$ for males, giving a female to male ratio of 2.69:1.00 in Topçam Dam Lake, Turkey (Şaşı \& Balık, 2003), 55.06\% for females and $44.95 \%$ for males in Sir Dam Lake, Turkey by Kara \& Solak, (2004), 59.80\% female and $40.20 \%$ male in Keban Dam Lake, Turkey by Aydın et al., (2015). The proportion of the various age groups in a population gives an important idea about the reproductive power of the population and the future status of the population (Nikolsky, 1963; King, 2007).

In the Beysehir dace samples in Oymapınar Dam Lake, maturation rates were examined based on length and age groups, it was observed that the females get to sexual maturity from $26 \mathrm{~cm}$ and males get to sexual maturity from $23 \mathrm{~cm}$. The males attain sexual maturity from age II while the females attain sexual maturity from age III. In the studies by Kara \& Solak, (2004) in Sır Dam Lake and Kılıç, (2011) in Yeniçağa Lake, it was reported that both females and males attained sexual maturity at age II. Nikolsky, (1963) stated that the age at first sexual maturity varies depending on water temperature, nutrition, growth rate and population density and that the growth rate of males in the first years is higher than females which might make the males reach sexual maturity one or two years earlier than females.

Appropriate identification of the maturity status of fishes is a fundamental strategy for the appropriate management of exploited stocks in the fishery and is a 
commonly used tool by fisheries' biologists and managers (Rahman et al., 2018). The monthly average GSI values of males and females were high from February to June and were highest in April. The lowest and highest GSI values were 0.73 and 3.32 for females and 0.72 and 4.02 for male S. anatolicus. The spawning season for Beysehir daces in Oymapınar Dam Lake from this study is between April and June which falls within the highest GSI values recorded in this study. This is in close agreement with the studies conducted in Sir Dam Lake by (Kara \& Solak, 2004) and Yeniçağa Lake by Kılıç, (2011), that reported the spawning seasons of chubs in these lakes to be between April and July. The spawning season of the species belonging to the Squalius genus may vary according to the regions and species. In a study conducted by Herzig \& Winkler, (1986), the spawning period for Beysehir dace was found to be between April-May and it was stated that if the altitude is more than $1000 \mathrm{~m}$, the spawning season may extend to June (Ekmekçi, 1996).

Knowledge of the fecundity of fish is important to examine the potential of its stocks, life history, practical culture, and actual management of the fishery (Islam et al., 2012). The range and mean fecundity of $S$. anatolicus in Oymapınar Dam Lake varied between 16116-53776, $29306 \pm 6750$ for age group III to $156643-208134,174710$ \pm 16730 for age group VIII fish, respectively with an average fecundity of 78408 . These values were greater than the fecundity range of $2,100-66,400$ per female for chub in Topçam Dam Lake (Şaşı 2004). The mean fecundity correlated positively with the age group and fork lengths of the fish. Ekmekçi, (1996), and Erdoğan et al., (2002) also reported a positive correlation between the age group, fork length and fecundity. In these investigations, it is reported that fecundity increased, as fish length, weight, age, and gonad weight increased. Fecundity is affected by age, size, species, feeding, season, and environmental conditions (Nikolsky, 1969).

The mean egg diameters of $S$. anatolicus in Oymapınar Dam Lake varied between $0.71 \mathrm{~mm}$ and 1.22 $\mathrm{mm}$ with a mean value of $0.93 \mathrm{~mm}$. The largest mean egg diameter was recorded in June while the smallest was recorded in November. The egg diameter values recorded in this study is in line with Türkmen, (1999) that reported a mean egg diameter of 0.92 to 1.45 for chubs in River Aras. The findings of this study are also close agreement with that of K1lıç \& Becer, (2016) for the chub population in Lake Yeniçağa. The egg diameter of a fish might vary with the fish length, weight, age, and gonad weight (Şaşı, 2004). One of the most important parameters used to define reproductive potential is the variation of egg diameter in the ovaries. Nikolsky, (1963) stated that egg diameter may be related to the amount of food that females can metabolise.

\section{CONCLUSION}

This study is important as it was the first research on the reproductive biology of $S$. anatolicus in Oymapinar Dam Lake. The reproduction status of Beysehir dace in Oymapinar Dam Lake was good. The fecundity of Beysehir dace in Oymapınar Dam Lake was higher compared to those in other Turkish lakes and dam lakes which could be due to nutritional, environmental, or climatic factors associated with the different areas where the lakes and dam lakes are located. Furthermore, Beysehir daces have extended spawning seasons in Oymapınar Dam Lake (April - June). Therefore, during this spawning season, there should be a closed fishing season for Beysehir daces in Oymapınar Dam Lake. Long-term monitoring on reproduction potential, spawning season, and population status of Beysehir dace should be done for sustainable fishery utilization in Oymapınar Dam Lake.

\section{REFERENCES}

Anderson, J.A. \& Alford, A.B. (2014). Ghost fishing activity in derelict blue crab traps in Louisiana. Marine Pollution Bulletin, 79, 261-267. DOI: 10.1016/j.marpolbul.2013.12.002

Anonymous, (2021). Oymapınar Barajı. Access date: 04.05.2021 http://www.akseki.gov.tr/oymapinarbaraji

Avşar, D. (2005). Balıkçılık biyolojisi ve popülasyon dinamiği. Nobel Kitabevi, Adana, Turkey, 110 p. [in Turkish]

Aydın, R., Yüce, S., Şen, D., Çoban, M.Z., Birici, N., Uslu, A.A. \& Küçükyılmaz, M. (2015). Keban Baraj Gölü'nde yaşayan tatlısu kefali (Squalius cephalus, L., 1758)'nin büyüme özellikleri. Yunus Araştırma Bülteni, 15(2), 59-69. DOI: 10.17693/yunusae.v15i21956.235766 [in Turkish]

Aykurt, H. \& Altınok Y. (2009). Oymapınar Baraj1 tetiklenmiş depremselliği ve deprem karakteristiklerinin incelenmesi. Istanbul Yerbilimleri Dergisi, 22(1), 49-66. [in Turkish]

Bagenal, T.B. \& Tesch, F.W. (1978). Age and growth. In: T. Bagenal (Ed.) Methods for assessment of fish in freshwaters, 3rd ed., 101-136p, Blackwell Scientific Publications, Oxford, UK.

Balık, S., Hasan, M., Sarı, M., Ustaoğlu, R. \& İlhan, A. (2004). Işıklı Gölü (Çivril, Denizli, Türkiye) tatlısu kefali (Leuciscus cephalus L., 1758) populasyonunun yaş ve büyüme özellikleri. E.Ü. Su Ürünleri Dergisi/E.U. Journal of Fisheries \& Aquatic Sciences, 21(3-4), 257-262. DOI: 10.12714/egejfas.2004.21.3.5000157006 [in Turkish]

Bogutskaya, N.G. (1997). Contribution to the knowledge of leuciscine fishes of Asia Minor. Part 2. An annotated checklist of leuciscine fishes 
(Leuciscinae, Cyprinidae) of Turkey with descriptions of a new species and two new subspecies. Mitteilungen aus dem Hamburgischen Zoologischen Museum und Institut, 94, 161-186.

Cochrane, K.L. (2002). A fishery manager's guidebook: management measures and their application. In: FAO fisheries technical paper. No. 424. FAO, Rome, 513p.

Demirol, F., Gündüz, F., Yıldız, N., Kurtoğlu, M., Çoban, M.Z. \& Yüksel, F. (2016). Some growth parameters of chub (Squalius cephalus) living in Uzunçayır Dam Lake (Tunceli-Turkey). Limnofish-Journal of Limnology and Freshwater Fisheries Research, 2(2), 67-76. DOI: 10.17216/LimnoFish-5000125245

Düzgüneş, O., Kesici, T., Kavuncu, O. \& Gürbüz, F. (1987). Araştırma ve deneme metodlarl (istatistik metodlar1-II). Ankara Üniversitesi Ziraat Fakültesi Yayınları, No 1021, Ankara 381 p. [in Turkish]

Ekmekci, F. G. (1996). Growth and reproduction properties of Chub (Leuciscus cephalus Linnaeus, 1758) in Sarıyar Dam Lake, (in Turkish). Turkish Journal of Zoology, 20, 95-106.

Erdoğan, O., Türkmen, M. \& Yıldırım, A. (2002). Studies on the age, growth, and reproduction characteristics of the Chub, Leuciscus cephalus orientalis (Nordmann, 1840) in Karasu River. Turkish Journal of Veterinary and Animal Sciences, 26, 983-991.

Gayanilo, F.C., Sparre, P. \& Pauly, D. (1996). The FAOICLARM stock assessment tools (FiSAT II) Users Guide In: FAO Computerized Information Series (Fisheries), FAO, Rome $126 \mathrm{p}$.

Herzig, A. and Winkler, H. (1986). The influence of temperature on the embryonic development of three cyprinid fishes, Abramis brama, Chalcalburnus chalcoides mento and Vimba vimba. Journal of Fish Biology, 28, 171-181.

Hossain, M.Y., Hossen, M.A., Islam, M.S., Jasmine, S., Nawer, F. \& Rahman, M.M. (2017). Reproductive biology of Pethia ticto (Cyprinidae) from the Gorai River (SW Bangladesh). Journal of Applied Ichthyology, 33, 1007-14. DOI: 10.1111/jai.13427

Islam, M.R., Sultana, N., Hossain, M.B. \& Mondal, S. (2012). Estimation of fecundity and gonadosomatic index (GSI) of gangetic whiting, Sillaginopsis panijus (Hamilton, 1822) from the Meghna River Estuary, Bangladesh. World Applied Sciences Journal, 17(10), 1253-1260.

Kaptan, S. (1995). Bilimsel araştırma ve istatistik teknikleri. Bilim Yayınları, Ankara, Turkey 290 p. [in Turkish]

Kara, C. \& Solak, K. (2004). Sır Baraj Gölü (Kahramanmaraş)'nde yaşayan Tatlısu Kefali (Leuciscus cephalus L, 1758)'nin Büyüme Özellikleri. KSU. Journal of Science and Engineering, 7(2), 2004. [in Turkish]

Karataş, M. Başusta, N. \& Gökçe, M. A. (2005). Balıklarda üreme, In: M. Karataş (Ed.), Balık biyolojisi araştırma yöntemleri, 61-69p, Nobel Yayın Dağıtım, Ankara, Turkey

Khatun, D., Hossain, M.Y., Nawer, F., Mostafa, A.A. \& AlAskar, A.A. (2019). Reproduction of Eutropiichthys vacha (Schilbeidae) in the Ganges River (NW Bangladesh) with special reference to the potential influence of climate variability. Environmental
Science Pollution Research, 26, 10800-10815. DOI: 10.1007/s11356-019-04523-5

Kılıç, S. \& Becer, Z. A. (2016). Growth and reproduction of Chub (Squalius cephalus) in Lake Yeniçağa, Bolu, Turkey. International Journal of Agriculture \& Biology, 18, 419-424. DOI: 10.17957/IJAB/15.0106

Kılıç, S. (2011). Yeniçağa Gölü'ndeki (Bolu) tatlısu kefali (Squalius cephalus (L., 1758)) ve kadife (Tinca tinca L., 1758) balıklarının populasyon dinamiğinin incelenmesi. Doktora tezi, Sü Ürünleri, Akdeniz Üniversitesi, Antalya, Turkey. [in Turkish]

King, M. (2007). Fisheries biology, assessment, and management. 2nd edition, Wiley-Blackwell Oxford, $\mathrm{UK}, 382 \mathrm{p}$.

Kırankaya, S.G. \& Ekmekçi, F.G. (2007). Gelingüllü Baraj Gölü'ndeki tatlısu kefalinin (Squalius cephalus, L., 1758) büyüme özelliklerindeki değişimler. Balıkesir Üniversitesi Fen Bilimleri Enstitüsü Dergisi, 9(2), 125-134. [in Turkish]

Nikolsky, G.V. (1963). The ecology of fishes. Academic Press, London and New York $352 \mathrm{p}$.

Rahman, M.M., Hossain, M.Y., Tumpa, A.S., Hossain, M.I., Billah, M.M. \& Ohtomi, J. (2018). Size at sexual maturity and fecundity of the mola carplet, Amblypharyngodon mola (Hamilton 1822) (Cyprinidae) in the Ganges River, Bangladesh. Zoology and Ecology 28(2), 1-8. DOI: $10.1080 / 21658005.2018 .1537906$

Ricker, W.E. (1973). Linear regressions in fishery research. Journal of the Fisheries Board of Canada,30, 409434. DOI: 10.1139/f73-072

Ricker, W.E. (1975). Computations and interpretation of biological statistics of fish populations. Bulletin of the Fisheries Research of Canada, 191, 382 p.

Şaşı, H. \& Balık, S. (2003). Topçam Baraj Gölü'ndeki (Aydın) Tatlısu Kefalinin (Leuciscus cephalusL., 1758) yaş, büyüme ve cinsiyet oranları. E. $U$. Journal of Fisheries \& Aquatic Sciences, 20(3-4), 503-515. [in Turkish]

Şaşı, H. (2004). The reproduction biology of Chub (Leuciscus cephalus L. 1758) in Topçam Dam Lake (Aydın, Turkey). Turkish Journal of Veterinary and Animal Sciences, 28, 693-699

Temesgen, M. (2017). Status and trends of fish and fisheries in a tropical rift valley lake, Lake Langeno, Ethiopia. Ababa University, Department of Zoological Sciences, Addis Ababa, Ethiopia; 2017, 190p.

Tessema, A., Getahun, A., Mengistou, S., Fetahi, T. \& Dejen. E. (2020). Reproductive biology of common carp (Cyprinus carpio Linnaeus, 1758) in Lake Hayq, Ethiopia. Fish Aquatic Science, 23, 16. DOI: 10.1186/s41240-020-00162-x

Tümgelir, L., Çubuk, H., Çınar, Ş., Özkök, R., Küçükkara, R., Ceylan, M., Erol, K.G. \& Çetinkaya, S. (2007). Beyşehir Gölü'ndeki Tatlısu Kefali (Leuciscus lepidus Heckel, 1843) popülasyonunun büyüme özellikleri. Ulusal $\mathrm{Su}$ Günleri, Antalya. Türk Sucul Yaşam Dergisi, 5-8, 200-208. [in Turkish]

Türkmen, M., Haliloğlu, H.I., Erdoğan, O. \& Yıldırım, A. (1999). The growth and reproduction characteristics of Chub, Leuciscus cephalus orientalis (Nordmann, 1840) Living in the River Aras. Turkish Journal of Zoology, 23, 355-364. 